\title{
Factors Enhancing Household Nutrition Outcomes in Potato Value Chain in South-Western Uganda
}

\author{
Johnny Mugisha ${ }^{1}$, Robert Mwadime ${ }^{2}$, Christopher Sebatta ${ }^{1}$, Robert Gensi $^{3}$ \& Bernard Obaa ${ }^{4}$ \\ ${ }^{1}$ Department of Agribusiness and Natural Resource Economics, Makerere University, Kampala, Uganda \\ ${ }^{2}$ FHI360, USAID Community Connector project, Plot 15, Kitante Close, P.O. Box 5768, Kampala, Uganda \\ ${ }^{3}$ Gorta-SelfHelp Africa, Plot 42 Ministers' Village Ntinda, P.O. Box 34429 Kampala, Uganda \\ ${ }^{4}$ Department of Extension and Innovation Studies, Makerere University, Kampala, Uganda \\ Correspondence: Johnny Mugisha, Department of Agribusiness and Natural Resource Economics, Makerere \\ University P.O. Box 7062, Kampala, Uganda. Tel: 256-7-7315-5702. E-mail: johnnymugisha@gmail.com
}

\author{
Received: August 31, $2016 \quad$ Accepted: December 23, $2016 \quad$ Online Published: May 31, 2017 \\ doi:10.5539/jsd.v10n3p215 URL: https://doi.org/10.5539/jsd.v10n3p215
}

\begin{abstract}
In Uganda, agricultural commercialization has been promoted to reduce poverty and improve household food security. South-western Uganda, the major producer of potato, has been considered the food basket of the country but it has one of the highest prevalence rates of stunting in children under 5 . This study considered potato enterprise as a key pathway for enhancing household food and nutrition security because it has become a major income source and staple in the diets of many households in the area and most urban areas in the country. The objective was to determine factors that influence farm household nutrition and food security outcomes. Through a survey, data were collected from 434 randomly selected potato farmer households. Descriptive and econometric methods were used in data analysis. Results show that household dietary diversity score was low (3.2) for most (57\%) of the households. Only $38 \%$ were food secure. The main factors enhancing household nutrition outcomes were size of land, livestock units owned, proportion of household income spent on food, and education of household head, while farmer's experience in potato production had a negative effect. The size of land owned, crop diversification, income from potato, age and education of household head, and a famer being male enhanced household food security outcomes. The study recommends promoting improved production practices to maximize land productivity, integration of livestock in potato production, and training women and men in household food and nutrition and related use of income.
\end{abstract}

Keywords: food security, nutrition, potato, South-western Uganda

\section{Introduction}

Global food production has more than doubled with more varied diets, but over 800 million people are reportedly still hungry, and about two billion suffer from poor nutrition (UNEP, 2016). In Africa, majority of households depend on agriculture for their livelihood through selling part of what they produce and consuming the balance. In Uganda, the government first through the Plan for modernization of Agriculture and later the National Agricultural Advisory Services, currently Operation Wealth creation, has been promoting agricultural commercialization. The strategic objective has been to reduce poverty and improve household food security (Ministry of Agriculture Animal Industry and Fisheries and Ministry of Finance Planning and economic Development, 2000). However, in the presence of imperfect markets and high transaction costs smallholder farmers are less able to exploit all the potential gains from commercialization that would be critical in enhancing household nutrition (de Janvry, 1991; Goetz, 1992). They do not always draw nutritional benefits from higher agricultural production, hence poor nutrition in children and women could occur even in good crop harvest years because though agriculture is essential it is not adequate to alleviate under nutrition (Gillespie, Harris, \& Kadiyala, 2012). Food quality in terms of safety and nutrient mix, the health of household members, care and feeding of the children and women are key factors in nutrition and are also influenced through the production system, especially among smallholder farmers, among whom most rural malnutrition occur. It is essential for designers of programs aimed at alleviating poverty or reducing under nutrition through agriculture interventions to understand how prevailing (or new) agricultural systems may affect nutrition outcomes. The focus should be 
on the social and production interactions and behaviors that take place during production, harvesting, selling of the farm produce - if any - to consumption, and how they affect poverty and nutrition outcomes (Gillespie et al., 2012). Three pathways of how agriculture can influence nutrition of smallholder farm households have been documented (Herforth \& Jody, 2014; Gillespie et al., 2012; World Bank, 2007): a) through increased agricultural production, handling or quality improvement to avail more food in the house through quantity produced or lower prices for food procured, b) increased household income that can be used to increase access to quality food, care and health, c) addressing gender issues that may affect care, access to food and feeding practices, and use of health care.

The amounts and nutritional quality of foods produced in smallholder households depend on various factors. Literature, such as Rahim, Saeed, Rasoo and Saeed (2011) and Zakari, Ying and Song (2014), shows that these factors are food production-specific (affecting the production pathway). For example, Faridi and Wadood (2010) found total land owned by a household to have a significant positive impact on food security status. Other factors include, use of fertilizers and improvement of soil fertility, irrigation, and use of indigenous high-nutrient-value crops or genetic modified plants with improve micronutrient supplies. This clearly spells out a direct linkage between household food and nutrition and agriculture (agricultural production pathway). However, there are many rural households that cannot sustainably ensure nutrition security through their own production either because they produce at small subsistence level or they are engaged in nonfood production activities and need some income to purchase additional food to meet their household food and nutrition requirements (income pathway). Whereas access to market was expected to positively influence food availability, Zakari et al. (2014) observed the contrary, explained by the tendency of households selling produce at harvest at low prices and relying on markets when there is scarcity at higher prices. High market prices of food are associated with low food security status (Faridi and Wadood, 2010) especially for the households that are net food buyers. Higher household size and dependency ratio have also been reported to negatively affect food security and nutrition of a household, with increase in household income and expenditure on food increasing the probability of a household being food secure (Otunaiya \& Ibidunni, 2014). In Ethiopia, Gebre (2012) found a positive relationship between education level of household head, asset possession, access to employment, credit services, and household food security.

The gender pathway considers gender relations at household and women empowerment in decision making and control over income. Studies show that men and women in a household have different resource allocation preferences, which has an effect on the household's food and nutrition security (Quisumbing \& Maluccio, 2003). For instance, Djebbari (2005) observed that in rural Mexico increasing non-labor income of a wife had a positive effect on total calorie consumption, while increasing the income of a husband had insignificant effect. The author further reported that food consumption increased when a female household member started earning, but it decreased substantively when a male household member started earning income. Fafchamps, Kebede and Quisumbing (2009) also noted positive effects of female bargaining power on child nutrition in Ethiopia. However, the positive relationships between agricultural commercialization and market access to create higher income and access a bundle of food with the needed nutrition value may not work in all places at all times because of limited resources. The issue is not necessarily to produce all the [quantity and quality] food a household needs, but how to utilize the little that is produced and how income derived from agriculture is actually utilized, especially the degree to which expenditures are allocated to foods with high nutrition value, health and care.

Agricultural investments should target the key agricultural enterprises in a given area and focus on how the entire value chain affects the different pathways that may affect nutritional outcomes. Interventions to improve nutrition are normally designed to target one or two of the key pathways namely: production pathway, income pathway and gender pathway (Herforth and Jody, 2014; Gillespie et al., 2012; World Bank, 2007). Hawkes and Ruel (2011) noted that value-chain approaches have rarely been used explicitly as a tool to achieve nutritional goals, describing it as "a missing opportunity". The linkage between the value chain and the nutrition and food security outcomes of the chain actors, especially among the smallholder farmers is not well known. The question of which pathway (production, income or gender) has more positive contribution on household food security, income and nutrition remain unanswered. The purpose of this study was therefore to get a deeper understanding of appropriate pathways that effectively and efficiently contribute to nutrition outcomes. The main objective was to map the potato value chain, determine factors that influence farm household nutrition and food security outcomes, and identify opportunities for interventions that enhance nutritionalization of the smallholders' potato value chain. We chose potato because it has increasingly become a major income source and staple in the diets of many households in South-western Uganda and most urban areas in the country. It has as a result attracted an 
increasing number of value chain actors (input suppliers, farmers, traders and processors), making it a good pathway for enhancing household food and nutrition security. However, very few studies have documented the interrelationships among the potato value chain actors and the actors' activities and value added. These include Lemaga (2010) on potato in Eastern Africa; Hoeffler (2006) and Mutunga (2014) on potato in Kenya; Alemu (2014) and Emana and Nigussie (2011) in Ethiopia; and Kyomugisha, Mugisha and Sebatta (in Press) in Uganda. We build on these studies to construct and validate the potato value chain in South-western Uganda with main reference to the study by Sebatta, Mugisha, Katungi, Kashaaru and Kyomugisha (2014) and Kyomugisha et al. (in Press).

Many and interrelated variables are responsible for the nutrition outcomes of household members, including household characteristics, gender, level of farm diversification, household resources, and level of farm commercialization (Figure 1). Among the household characteristics are household size (Rahim et al., 2011), education level (Gebre, 2012) and age of household head who is the decision-maker (Oluyole, Oni, Omonona \& Adenegan, 2009), and household composition. The size of the household determines the adequacy of food available to each member (per capita food consumption) and the nutrient quality of the food. In a situation where a household is faced with limited access to productive resources and income, an increase in its size negatively affects the nutrition status of the members. The situation is worse when the additional person is a dependent (Otunaiya \& Ibidunni, 2014).

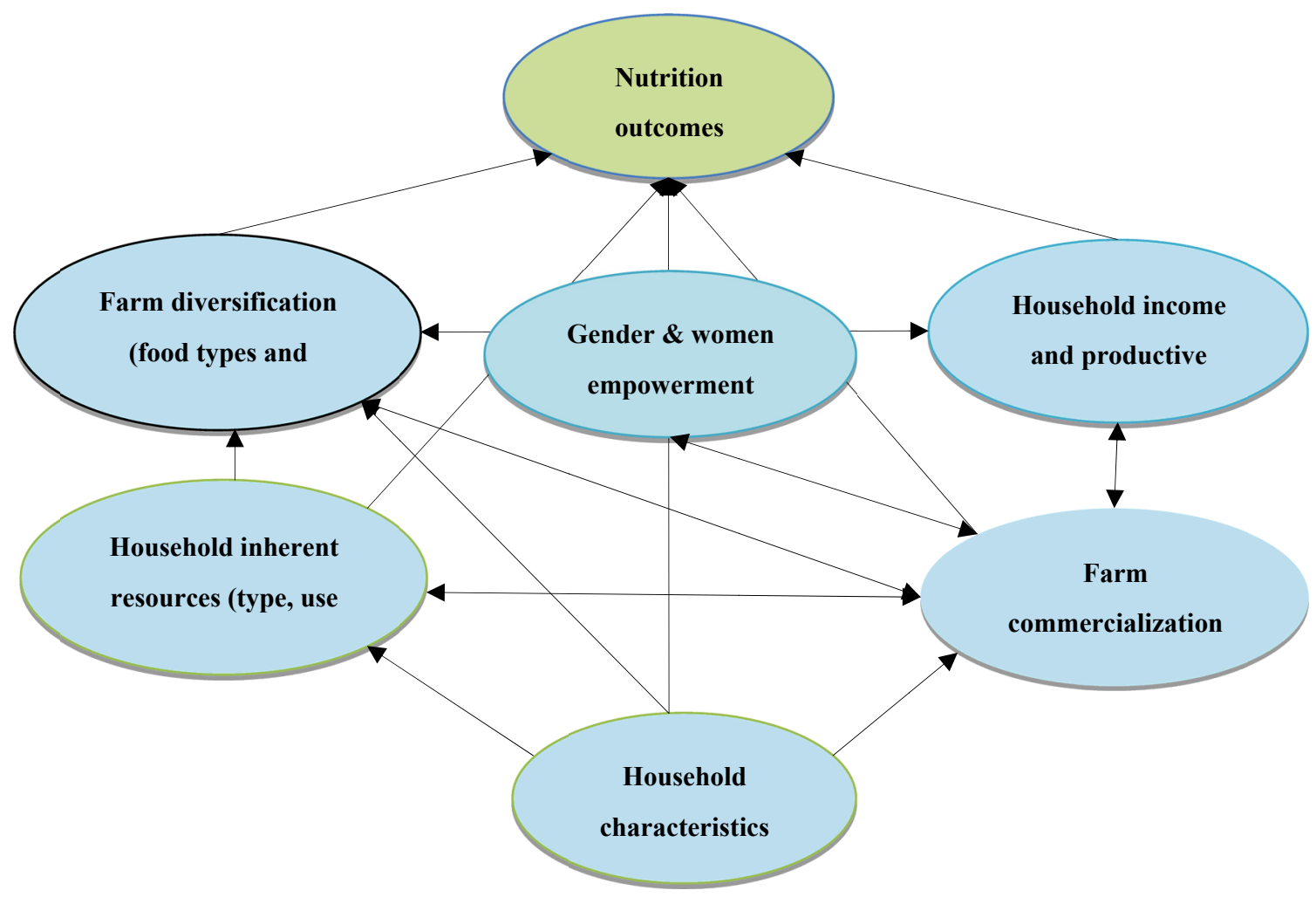

Figure 1. Interrelationships between key variables determining household nutrition outcomes

The household characteristics also influence the level of farm diversification, which also has an implication on how the different household resources are utilized. Farm diversification can positively improve household food and nutrition outcomes by increasing household's access to a diversified diet and to nutrient rich foods (Immink \& Alarcón, 1992) from own production. However, this depends on the types of crops and animals in the diversified farm and the level of resources allocated to the farm. Household nutrition outcomes is negatively affected if, for example, a farm is highly diversified but in non-food crops unless they are sold and the income got is used to buy a diversity of foods. Similarly, the diversification could be foods of the same group (e.g. high carbohydrate foods), or household resources could be so limited that they are thinly allocated to so many farm enterprises to an extent that very low outputs of each are realized. As such diversification per se is not sufficient 
in ensuring household nutrition. Kikafunda, Agaba and Bambona (2014) noted areas where total amount of food seemed to be sufficient, but with households facing difficulties in achieving a diversified diet.

Farm commercialization has also been cited as driver for household nutrition through the production-income pathway. With commercialization, households get income that enables them to purchase a diversity of foods as Babatunde, Omotesho and Sholotan (2007) reported that households with more income are more food secure. However, the level of commercialization and the income pathway in general are affected by, among other factors, market prices which if not favorable affect what types of food a household buys, and how much of the income received is spent on food. It also depends on how nutrition-sensitive the household decision-maker and controller of income is. Promoters of commercialization (and the income pathway) assume that households will sell their produce and use the income to buy a diversified diet or improved health. However, there is a risk of spending the income on non-food and/or foods of low nutrition value. This is why gender pathway becomes important in household food and nutrition, particularly the level of women involvement in food production and utilization, decision making and control of resources and income, and the level of her knowledge in nutrition. Within a household, it is the male and female interaction in production and consumption which determines choices about farm diversification and use of resources (Whitehead, 1990). This may affect the level to which farming is commercialized and how the incomes realized are allocated to food and non-food needs of a household. In this study, we use the proportion of harvested potato that is sold, size of land allocated to potato and use of improved purchased inputs in potato production to represent level of commercialization. This is because potato was the major commercial and food crop in the area.

\section{Methodology}

\subsection{Description of Study Area}

This study was conducted in three South-western districts of Uganda namely; Kabale, Kisoro and Kanungu. South-western Uganda has been considered the food basket of the country, but it has one of the highest prevalence rates of stunting (next to Karamoja region) in children under 5 (Leliveld, Dietz, Foeken \& Klaver, 2013). The region, particularly Kabale, Kanungu, Kisoro districts, is characterized by high population density, small land sizes, relatively low levels of poverty but with high disparity, and overweight among women. The three districts were for this reason purposively selected. In addition, they are the major potato producers in the country, and they have been receiving value chain support from a number of programs to address malnutrition and livelihood including the USAID Community Connector (USAID/CC) Project. The USAID/CC Project works with local governments to improve the nutritional status of women and children, and the livelihoods of vulnerable populations through sustainable, integrated nutrition and agriculture interventions at the community and household levels. It promotes a range of practices and technologies across different enterprises including potato in South-western Uganda as a mechanism to avert the food and nutrition insecurity.

Generally, the potato enterprise in South-western Uganda has enjoyed a lot of research and support from among others, the government through National Agricultural Research organization (NARO) and development agencies. However, much of the research and development interventions have focused on potato agronomy and production, with no research looking at the linkage between the value chain and nutrition of the chain actors particularly the smallholder farmers.

\subsection{Study Design, Sampling Procedures and Data Collection}

This study was cross-sectional targeting potato growing households. The major potato producing sub-counties within the three districts were purposively selected using a stratified random sampling. These are Ikumba, Hamurwa and Muko sub-counties in Kabale district, Bukimbiri in Kisoro, and Kihihi, Rutenga and Rugyeyo in Kanungu. A random sample of 434 farm households was selected in each of the selected sub-counties. Farm household surveys, during which farmers were interviewed by trained enumerators, were conducted to collect both quantitative and qualitative data. The interviews were conducted in local language using a pre-tested questionnaire. The data collected included: household farm resources owned and quantities allocated to potato production; inputs used in potato production; value chain actors and their roles; quantities harvested, consumed and sold and the prices. Other information was on diversity of farm production; food types consumed by the households; sources of the foods; quantities and prices of the foods; income sources available in the area and how the income earned was used.

\subsection{Data Analysis}

The farm households were categorized as largely commercialized, semi-commercialized and largely subsistence. Farm commercialization has generally been defined as a ratio of the output sold to total output harvested. However, 
using this computation in potato in South-western Uganda would be misleading because the crop is the main source of income for most households and even the subsistence farmers may sell all the potato produced to get income for other household needs. In such a case, the computed ratio would categorize such farmers as commercial To overcome this limitation, we considered the level of farm resources (land and purchased capital inputs) allocated to the crop in addition to the proportion of potato sold. South-western Uganda is known for its land scarcity, so one would not expect farmers to allocate much more land to only one crop yet they have to diversify. The considered purchased inputs are improved seed, fertilizers and pesticides. Market-oriented or commercial farmers are profit-driven and hence go for yield improving inputs to maximise yields and revenue. Regarding proportions sold, potato is both a food and cash crop in the area thus farmers have to balance between household food needs and income for other needs. As such, we defined the largely commercialized farm households as those allocating over $45 \%$ of crop land to potato, using at least two of the purchased capital inputs and selling over $65 \%$ of their harvested potato. Those allocating less than $15 \%$ of crop land to potato, not using any of the mentioned purchased inputs and selling less than $35 \%$ of their harvested potato were categorized as largely subsistence. The middle category, allocating $15-45 \%$ of crop land to potato, using at least two of the purchased inputs and selling $35-65 \%$ of their harvested potato were considered as semi-commercialized.

Descriptive and econometric methods were used to analyze the data. Descriptive analysis involved generating means, percentages and correlations. Econometric analysis was used to determine which factors, and therefore pathway(s), are associated with household nutrition outcomes. Household Dietary Diversity Score (HDDS) was used as a measure of household nutrition security (Swindale \& Bilinsky, 2005). Dietary diversity is a qualitative measure of food consumption that reflects household access to a variety of foods, and is also a proxy for nutrient adequacy of the diet taken. The food grouping (12 food groups) was adopted in determining the HDDS with a recall period of 24 hours. Swindale and Bilinsky (2005) reported that a more diversified diet is highly correlated with such factors as caloric and protein adequacy and likelihood of achieving micronutrient intake.

A Generalized Linear Model (GLM) was used to determine the factors in household nutrition outcome, with proportion of HDDS on a scale of 12 as the dependent variable. The model assumes a relationship between observations $y$ of the random response variable Y and a probability (density) function (Hilbe, 1994). GLM supports the development of a strategy for approaching statistical problems that involve non-normally distributed data, in a way that retains much of the simplicity of linear models. The model uses the assumption of exchangeability in that if $Y$ is the dependent variable, $X s$ are explanatory variables, that is,

$$
Y \equiv Y[U]=Y\left(u_{1}\right), \ldots, Y\left(u_{i}\right) \text { on sample units and } X \equiv X[U]=X\left(u_{1}\right), \ldots, X\left(u_{i}\right) .
$$

Assuming exchangeability, $X[U]=X\left[U^{\prime}\right]$ implies for all $U, U^{\prime} \subset U$

The GLM also assumes independence of error terms of the various sampling units in a way that

$Y\left(u_{1}\right), \ldots, Y\left(u_{n}\right)$ are independent. The $Y$ and the error term tend to a normal distribution so that

$Y \sim N\left(\mu=X \beta, \delta^{2} \ln \right), E(Y(U))=\beta_{1} X_{1}+\cdots+\beta_{p} X_{p}(u) \quad$ (McCullagh, 1980).

The model was therefore specified as in equation (1) and estimated as in equation (2). The variables in the model are defined in Table 1.

$$
\begin{gathered}
Y=\beta_{0}+\beta_{i} X_{i}+\cdots+\mu \\
H D D S_{S p}=\beta_{0}+\beta 1_{1} \text { Land }+\beta_{2} E x p+\beta_{3} T S L U+\beta_{4} C C+\beta_{5} C I+\beta_{6} P_{\text {Com }}+\beta_{7} Y_{A}+\beta_{8} P_{F E}+\beta_{9} Y_{P O}+ \\
\beta_{10} \text { Hed }+\beta_{11} \text { Sex }+\beta_{12} \text { Age }+\beta_{13} D R+\beta_{14} \text { Woy }+\beta_{15} W o C p+\beta_{16} \text { Wtrain }+\varepsilon_{i}
\end{gathered}
$$

The GLM was also used to determine factors affecting household food security outcomes, with proportion of Household Food Insecurity Access Scale (HFIAS) score as the dependent variable and independent variables as in equation (2). The HFIAS as used by Coates et al. (2007) was adopted to categorize households as: "food secure" (HFIAS of 0-1), "mild food insecurity" (HFIAS of 2-13), "moderate food insecurity" (HFIAS of 14-16), and "severe food insecurity" (HFIAS of 17-27). 
Table 1. Variable description and measurement for the GLM model

\begin{tabular}{|c|c|}
\hline Variable & Description \\
\hline$H D D S_{S p}$ & Proportion score of a household on the Household Dietary Diversity Score scale \\
\hline Land & Total land (ha) owned by the household \\
\hline $\operatorname{Exp}$ & Farmer's experience in potato production (Years) \\
\hline$T S L U$ & $\begin{array}{l}\text { Livestock numbers converted to a common unit. Conversion ratios used are: Cattle }=0.7 \text {, } \\
\text { heifers }=0.8 \text {, calves }=0.4 \text {, sheep } / \text { goat }=0.1, \text { pigs }=0.2 \text {, chicken } / \text { ducks }=0.01 \text { \& rabbits }=0.02 \\
\text { ((ILRI,2005; Eurostat, 2015) }\end{array}$ \\
\hline$C C$ & Dummy for being a USAID Community Connector Project participant \\
\hline$C I$ & $\begin{array}{l}\text { Crop diversification (ratio of number of crops a farmer grows to the number of crops grown in } \\
\text { the community, in this case the total number of crops is } 16 \text { ) }\end{array}$ \\
\hline$P_{\text {Com }}$ & $\begin{array}{l}\text { Potato commercialization computed as proportions of land and capital inputs allocated to } \\
\text { potato production and percentage of potato harvest sold }\end{array}$ \\
\hline$Y_{A}$ & Income from productive assets (UShs) \\
\hline$P_{F E}$ & Percentage of household income spent on buying food \\
\hline$Y_{P_{o}}$ & Total income (Uganda shillings) earned from potato annually \\
\hline Hed & Education level (years of schooling) of the household head \\
\hline $\operatorname{Sex}$ & Farmer's sex $($ Male $=1$, Female $=0)$ \\
\hline Age & Age of household head (Years) \\
\hline$D R$ & Household dependency ratio (Number of dependants per working household member) \\
\hline Woy & Woman decides how to spend her own income $(\mathrm{Yes}=1 ; \mathrm{No}=0)$ \\
\hline$W o C p$ & Woman decides how to use income from other crops other than potato $(\mathrm{Yes}=1 ; \mathrm{No}=0)$ \\
\hline Wtrain & Woman participates in agricultural trainings $(\mathrm{Yes}=1 ; \mathrm{No}=0)$ \\
\hline$\varepsilon$ & the error term \\
\hline
\end{tabular}

\subsection{Ethical Considerations, Data Management and Quality Control}

Before field data collection, the research team paid courtesy visits to Local Government authorities to inform them of the purpose and design of the study and to seek consent. At household level, the team first explained to the potential respondents the objectives of the study and sought their consent to be interviewed, assuring them confidentiality of their identities and the information provided. No respondent was coaxed to participate in the interviews. Each respondent and FGD participant was given the opportunity to ask questions and/or seek further clarification at the end of each interview. The filled questionnaires were cross-checked for consistency and validity while still in the field. Any gaps in the questionnaires were accordingly addressed. Responses to questions that were open-ended were coded. This was followed by data entry using SPSS computer software. Further data cleaning and editing were done to get a clean data set for storage and analysis.

\section{Results and Discussion}

\subsection{Potato Value Chain Mapping in South-western Uganda}

The current potato value chain in South-western Uganda is short; involving input suppliers, farmers, producers, traders and consumers. There is limited potato processing and the produce is traded in raw form. Each of the value chain actors play specific functions as elaborated below.

Producers/farmers: The study categorized potato farm households as subsistence, semi-commercial and commercial, and compared their social characteristics. The characteristics considered included sex of the household head and his/her marital status, age, level of education, household size and composition, and experience in potato. These are some of the variables hypothesized to influence food and nutrition outcomes of a household as highlighted by some previous studies such as Altman, Hart and Jacobs (2009), Campbell (1991), and Maxwell and Smith (1992). Results from the household survey (Table 2) showed that there were no significant differences in the considered household characteristics across the three categories of potato 
commercialization save household size. For instance, most of the household heads (over $80 \%$ ) at the different levels of potato commercialization were males. The majority $(85 \%)$ was married, and a small percentage (less than $30 \%$ ) had post primary school education. However, the size of the subsistence households was slightly bigger than that of the commercialized counterparts.

Table 2. Characteristics of potato farmers by level of commercialization, October 2015

\begin{tabular}{|c|c|c|c|c|c|}
\hline \multirow[t]{2}{*}{ Characteristic } & \multirow{2}{*}{$\begin{array}{l}\text { Overall } \\
\text { sample } \\
(n=434)\end{array}$} & \multicolumn{4}{|c|}{ Level of commercialization } \\
\hline & & $\begin{array}{c}\text { Subsistence } \\
(\mathbf{n}=\mathbf{3 2 5})\end{array}$ & $\begin{array}{l}\text { Semi-comme } \\
\text { rcial }(n=68)\end{array}$ & $\begin{array}{c}\text { Commercial } \\
(n=41)\end{array}$ & P-value \\
\hline Sex of household head is male (\%) & 83 & 83 & 82 & 80 & 0.92 \\
\hline $\begin{array}{l}\text { Farmer is a CC Project participant } \\
(\%)\end{array}$ & 41 & 42 & 41 & 29 & 0.27 \\
\hline $\begin{array}{l}\text { Marital status of household head is } \\
\text { Married (\%) }\end{array}$ & 85 & 86 & 78 & 85 & 0.23 \\
\hline $\begin{array}{l}\text { Education level of household head is } \\
\text { Post primary (\%) }\end{array}$ & 29 & 30 & 26 & 27 & 0.84 \\
\hline $\begin{array}{l}\text { Average age of household head } \\
\text { (years) }\end{array}$ & $43(14)$ & $43(14)$ & $43(14)$ & $40(13)$ & 0.88 \\
\hline Average household size & $6(2)$ & $6(2)$ & $5(2)$ & $5(2)$ & 0.06 \\
\hline $\begin{array}{l}\text { Average number of years in potato } \\
\text { farming }\end{array}$ & $12(12)$ & $12(11)$ & $14(14)$ & $12(12)$ & 0.22 \\
\hline
\end{tabular}

Figures in parentheses are standard deviations

In addition to potato, farm households in South-western Uganda grow a variety of crops including sweet potato, sorghum beans and peas. Table 3 shows that majority $(89 \%)$ of the interviewed households grow ware potato as the main crop. A comparison by level of commercialization shows that the percentage of subsistence farmers with major crops other than potato is generally higher than that of the more commercialized farmers. The latter tend to specialize in fewer crops.

Table 3. Major crops grown by potato farmers in South Western Uganda

\begin{tabular}{lcccc}
\hline Major crops grown & \multicolumn{4}{c}{ Percentage of farmer growing the crop as a main crop } \\
\cline { 2 - 5 } & $\begin{array}{c}\text { Overall sample } \\
(\mathbf{n}=\mathbf{4 3 4})\end{array}$ & $\begin{array}{c}\text { Subsistence } \\
(\mathbf{n = 3 2 5})\end{array}$ & $\begin{array}{c}\text { Semi-commercial(n=68) } \\
\text { Cemmercial(n=41) }\end{array}$ & Commec \\
\hline Seed potato & 19 & 19 & 16 & 20 \\
Ware potato & 89 & 90 & 85 & 93 \\
Sorghum & 16 & 17 & 18 & 7 \\
Beans & 45 & 43 & 46 & 2 \\
Sweet potato & 9 & 11 & 4 & 2 \\
Cabbages & 4 & 5 & 4 & 10 \\
Peas & 34 & 65 & 7 & \\
\hline
\end{tabular}

The majority of the farmers (see Table 4), both males and females, have knowledge on recommended technologies for improved production, such as use of positive selection for seed $(70 \%)$ and negative selection (76\%), proper use of agro-chemicals (74\%) and de-haulming(78\%). However, a smaller percentage as shown in the Table applies this knowledge. 
Table 4. Farmers' knowledge and use of recommended potato production practices

\begin{tabular}{|c|c|c|c|c|c|c|c|c|}
\hline \multirow[t]{2}{*}{ Practice } & \multicolumn{4}{|c|}{$\begin{array}{l}\text { Percentage of farmers with the } \\
\text { knowledge on practice }\end{array}$} & \multicolumn{4}{|c|}{$\begin{array}{c}\text { Percentage of farmers applying the } \\
\text { practices }\end{array}$} \\
\hline & $\begin{array}{l}\text { Overall } \\
\text { sample }\end{array}$ & Male & Female & p-value & $\begin{array}{l}\text { Overall } \\
\text { sample }\end{array}$ & Male & Female & p-value \\
\hline $\begin{array}{l}\text { Seed plot } \\
\text { technology }\end{array}$ & 55.3 & 54.6 & 58.7 & 0.519 & 34.1 & 32.6 & 41.3 & 0.146 \\
\hline Positive selection & 70.1 & 70.5 & 68.0 & 0.671 & 53.5 & 52.7 & 57.3 & 0.459 \\
\hline Negative selection & 76.0 & 76.0 & 76.0 & 0.993 & 74.4 & 74.9 & 72.0 & 0.597 \\
\hline Fertilizer use & 62.7 & 63.8 & 57.3 & 0.293 & 44.2 & 46.2 & 34.7 & 0.120 \\
\hline $\begin{array}{l}\text { Proper use of } \\
\text { agrochemicals }\end{array}$ & 74.4 & 76.3 & 65.3 & 0.047 & 68.2 & 71.3 & 53.3 & 0.017 \\
\hline $\begin{array}{l}\text { De-haulming } \\
\text { technology }\end{array}$ & 78.1 & 78.3 & 77.3 & 0.858 & 70.5 & 71.3 & 66.7 & 0.677 \\
\hline
\end{tabular}

Input dealers: Key inputs in potato production are seed, fertilizers and agro-chemicals. With its offices located in Kabale Municipality, the Uganda National Seed Potato Producers Association (UNSPPA) is the supplier of certified potato seed in the region. UNSPPA deals in certified seed from National Agricultural Research organization (NARO), multiplies it and sells it to farmers (at Ush140 000 per $80 \mathrm{~kg} \mathrm{bag}$ ) and to Local Government (Operation Wealth Creation) and organizations like International Fertilizer Development Center (IFDC) at higher price (Ush198 $000^{1}$ per $80 \mathrm{~kg}$ bag).

Traders: Potato traders are categorized into two: those operating from rural areas where potato production takes place (rural traders), and those located in urban areas (urban traders). They are further categorized as wholesalers and retailers. The retailers get supplies either from the wholesalers or directly from farmers. The wholesalers are mobile; they handle large volumes of potato procured from farmers either directly or through brokers. The traders purchase and sell potato in raw form. The value they add is limited to collecting potato from many small scale farmers, sorting, packaging and transporting to markets. They also do re-packaging in bags.

Processors: There are few potato processors in South-western Uganda; they operate on very small scale, mainly producing chips (Kyomugisha et al., in Press). They use simple tools, charcoal stove and frying pan, and operate in an informal market. By the time of the study, there was one large modern processor of potato crisps in Kabale, Uganda Industrial Research Institute Potato Research and Processing, buying potato directly from farmers. Another plant had been installed in Kisoro but not yet functional at that time.

Value chain supporters and facilitators: The potato value chain has been supported by a number of organizations. These include the USAID Community Connector Project, IFDC, Kachwekano Zonal Agricultural Research and Development Institute (KAZARDI), Local Government, Excel Hort Consult Ltd, and FAO.

\subsection{Sources of Income and Its Utilization by Potato Farm Households}

Farm households in South-western Uganda have a narrow spectrum of income sources. Results in Table 5 show that most of the household income is derived from agriculture, specifically potato and other crops, productive assets such as hiring out land, trees (tree sales), and livestock and livestock products. Of these sources, potato alone accounts for about $21 \%$ of the total annual income a household earns (19\%) among the subsistence households and 39\% among the commercial households). As it becomes more and more commercialized, potato tends to be more of a male farmer crop; accounting for $22 \%$ of the annual income for male farmers as compared to $17 \%$ for female farmers.

\footnotetext{
${ }^{1}$ During the study period, US $\$ 1=$ Ush 3500
} 
Table 5. Farmer household income, sources and expenditure

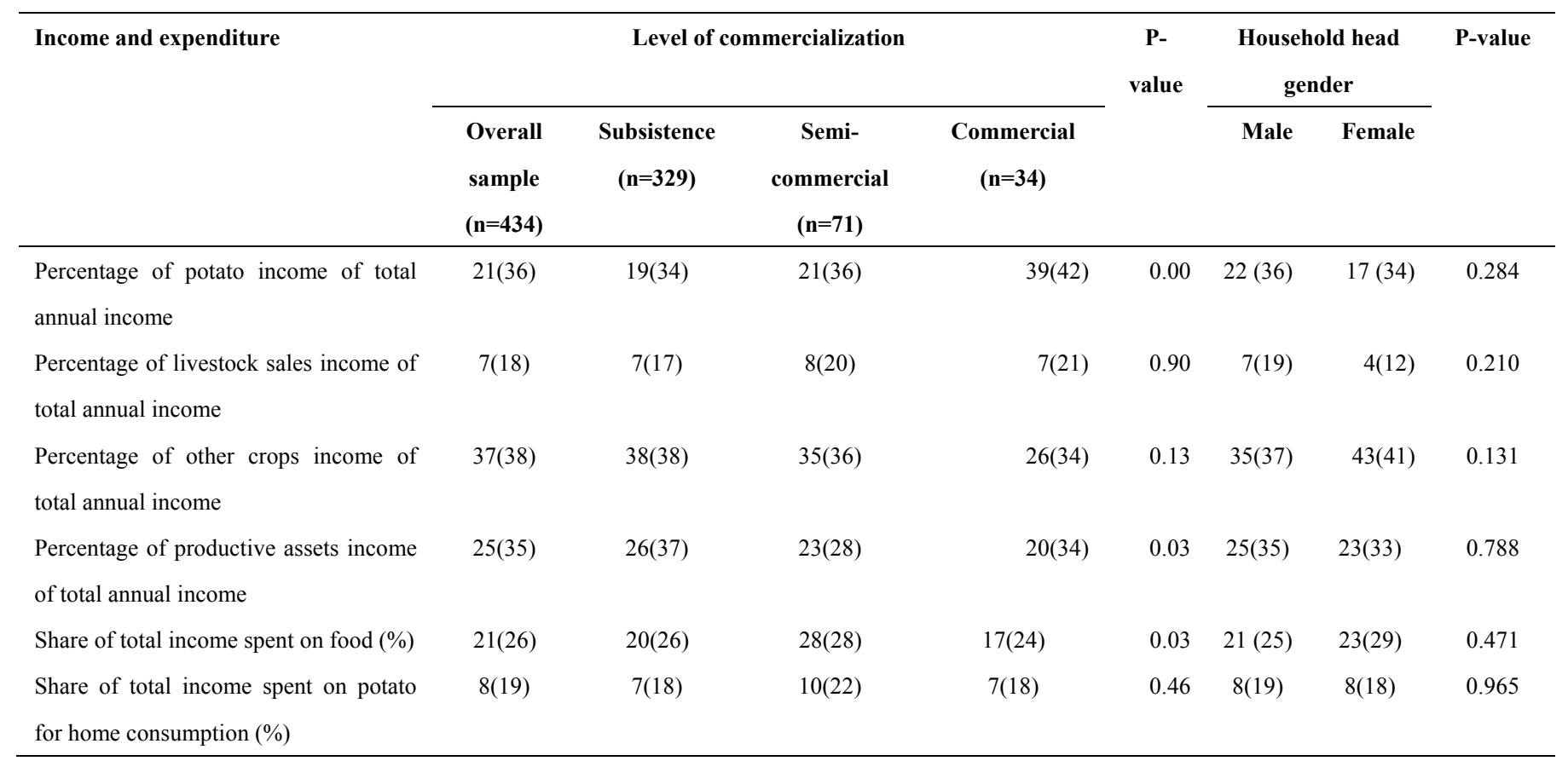

Figures in parentheses are standard deviations

About $21 \%$ of the income of farm household is spent on food (Table 5). The other portion is spent on non-food items mainly school fees for children. Among the foods purchased is potato, implying that even though the households are potato growers, some are not able to produce enough to meet the household food demand throughout the year. They are net potato sellers in some months and net buyers in other periods of the year (Sebatta et al., 2014).

\subsection{Household Food Security and Nutrition Outcomes}

The diets of both adults and children constituted beans (legume), maize (cereal), sweet potato (roots), potato (tubers) and amaranth (vegetables) as shown in Figure 2. For the children under 5 years, potato dominates the diet, with legumes serving as the main protein source. Animal protein and fruits are rare in the children's diets. Household own food production is not enough to satisfy the food needs; it is supplemented by food purchases especially cereals (rice and maize. Whereas about $80 \%$ of the households reportedly grew potato, some had to buy from the market to supplement their production. Some of them produce less than their food needs, while others sell them shortly after harvest either to get income for other needs or to avoid spoilage given their short shelf-life. The average household Dietary Diversity Score was 3.2 (Figure 3) and among children it was 2.3. About $57 \%$ of the households did not have economic ability to access a variety of foods. The diets were rich in carbohydrates (cereals and roots) but poor in micronutrients like vitamins $\mathrm{A}$ and $\mathrm{C}$ foods and animal protein sources. There was no significant difference between the dietary diversity for the subsistence, semi-commercialized and commercialized farm households. 


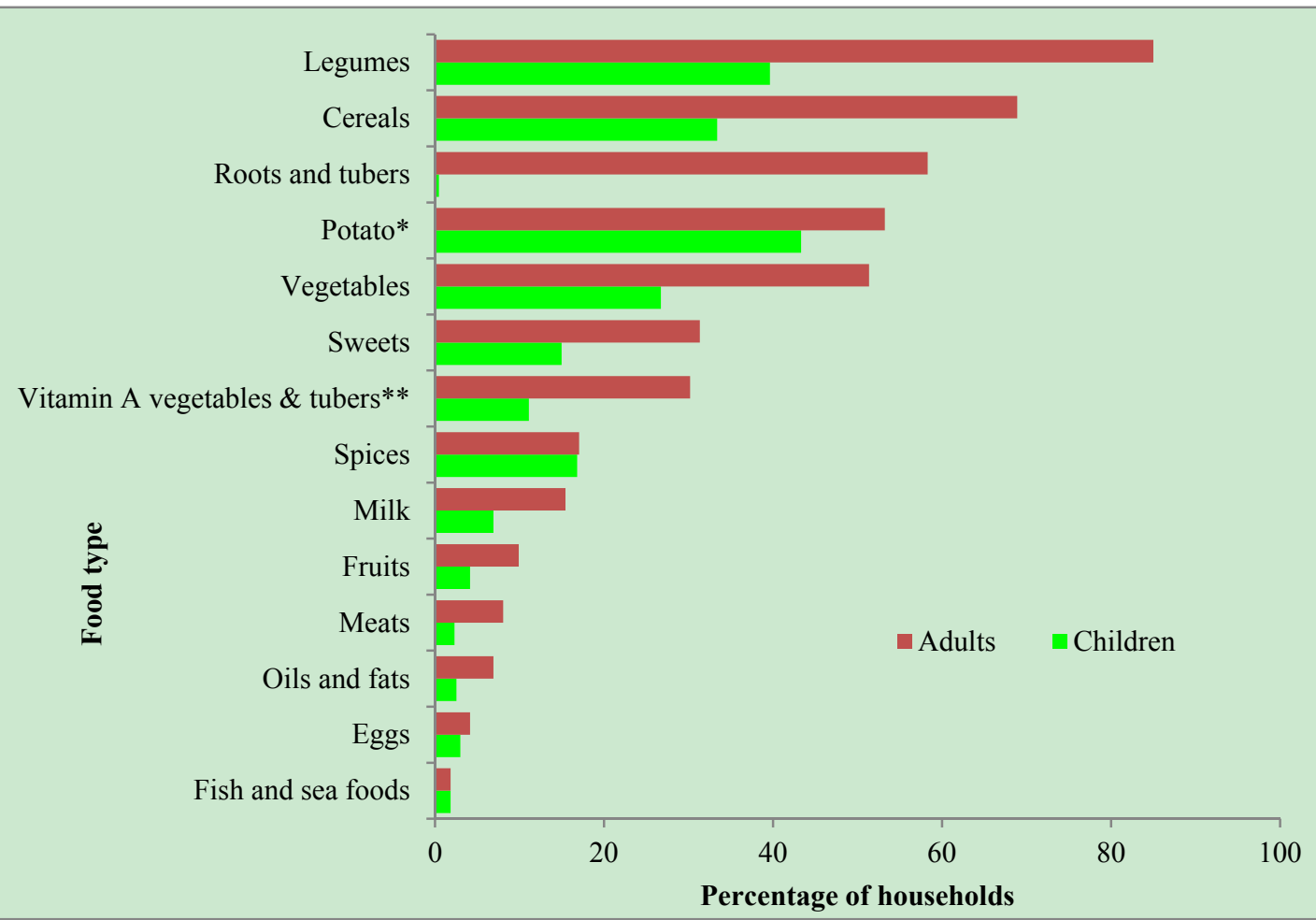

Figure 2. Percentages of farmer households consuming and feeding children $<5$ years on different food types in the previous 24 hours

Note: *Potato is not a food type. It is presented alone being the focus of the study

**Vitamin A vegetables \& tubers in this case excludes potato

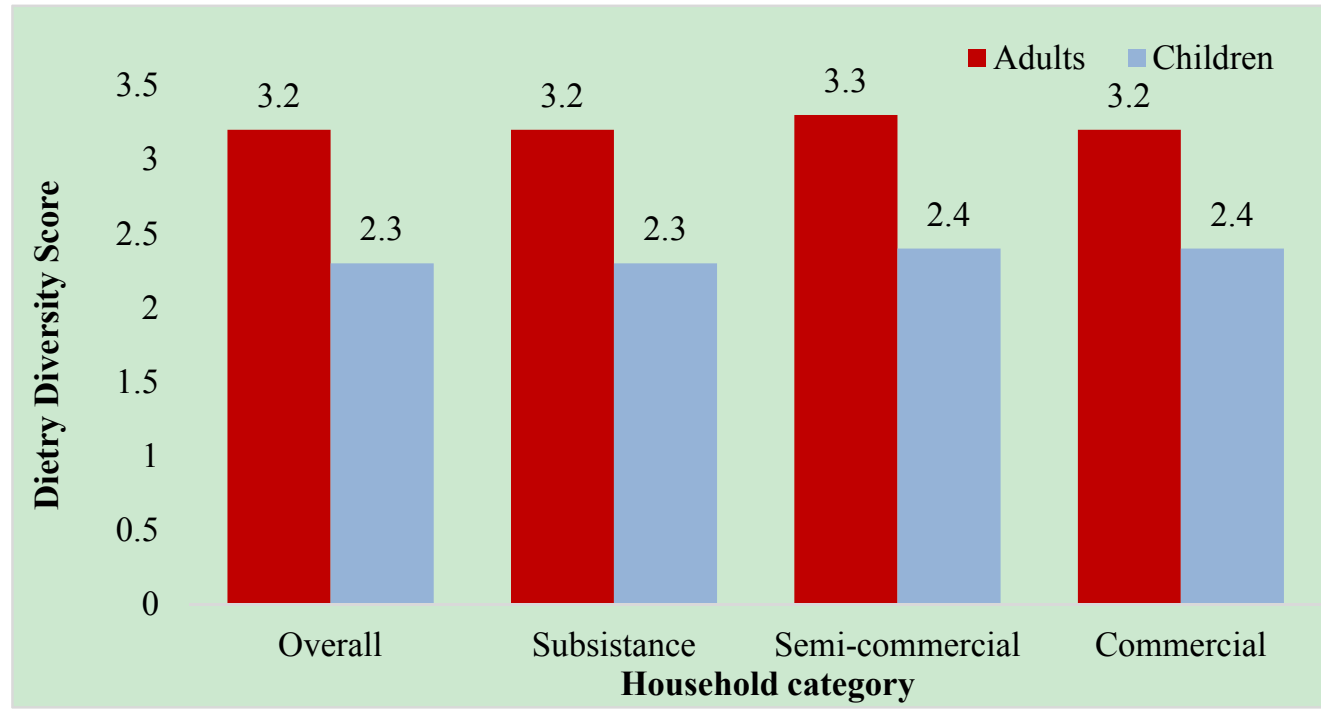

Figure 3. Mean Dietary Diversity Score for households and children by level of potato commercialization

The Household Food Insecurity Access Scale (HFIAS) was 4.8, which indicates that the households were on average mildly food insecure. In all the three household categories, the percentage (35-39\%) reporting to be food secure was the highest and not significantly different among the categories (Figure 5). The percentage reporting food insecurity (mild and moderate) was also not significantly different. However, a bigger percentage (24\%) of the commercialized households reported to be severely food insecure. This could be explained by the limited 
farm diversification coupled with selling out a larger portion of their potato harvest without using the income to buy other foodstuffs.

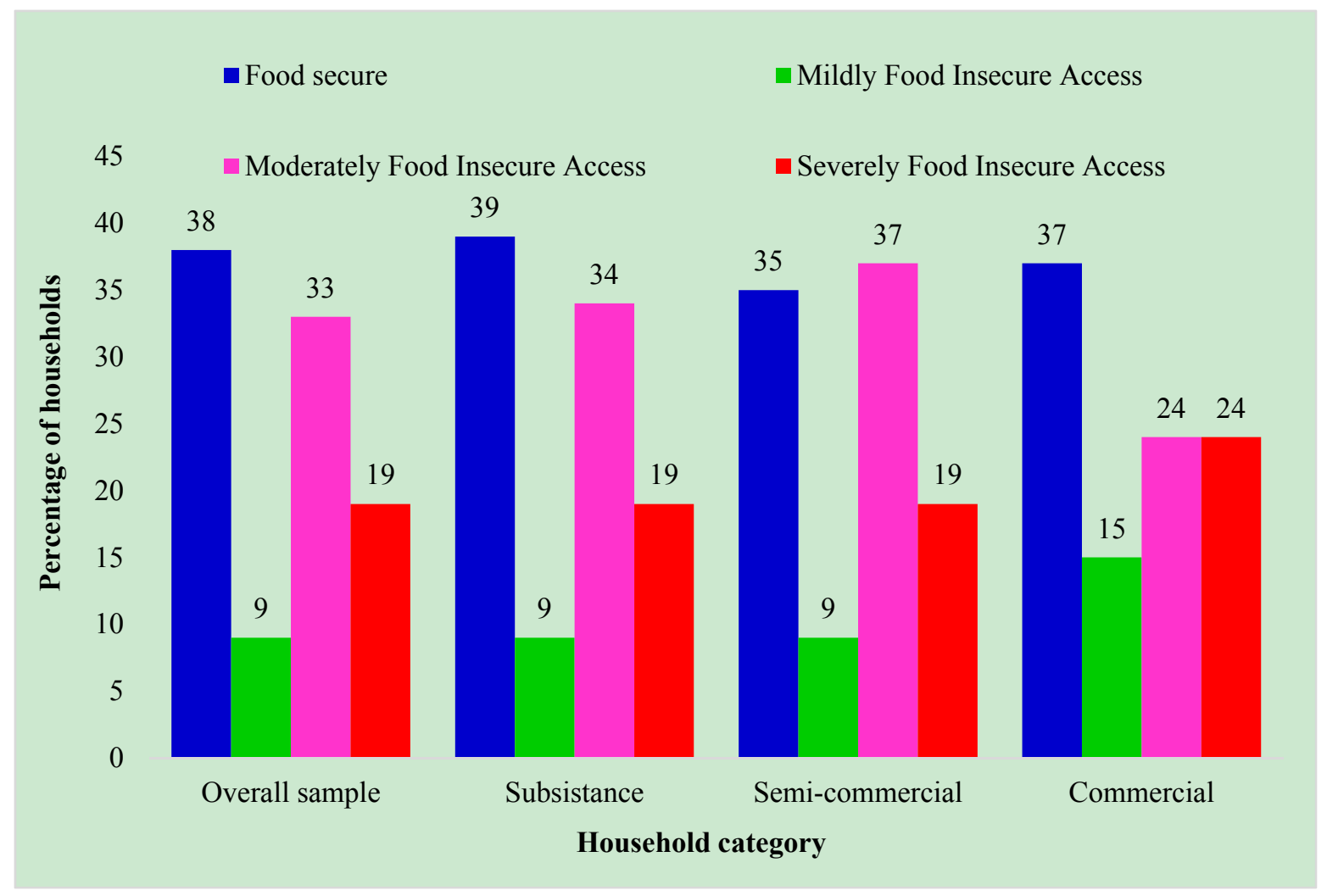

Figure 7. Household Food Insecurity Access by level of potato commercialization

\subsection{Factors Affecting Household Nutrition Outcome}

Results in Table 6 show the major factors that influence nutrition outcome of households in South-western Uganda. Most of the significant factors (size of land owned, farmer's experience in potato production, and Livestock Units owned) fall under the production pathway, with only one variable (proportion of household income spent on food) under the income pathway. Education level of the household head is also significant. No significant variable under the gender pathway.

As a priori expected, the size of land a household owns has a positive and significant $(\mathrm{P} \leq 0.01)$ influence on the household nutrition outcome, with every unit increase in land size owned by a potato farm household resulting into increase in its dietary diversity score. Land is a major factor of food production for the household, and the larger the land size, the more flexibility a household has to use it for food production. Nonetheless, farm crop diversification did not show a significant coefficient contrary to what some other studies have observed (Immink \& Alarcón, 1992; de Vries, Rabbinge \& Groot, 1997). Most crops produced in the study area belong to a narrow range of food types-mainly cereals, legumes, and roots and tubers. The crops households grow and consume are not diversified in terms of the food nutrients they provide; most are carbohydrate rich foods. 
Table 6. Factors for household dietary diversity score in Souh-western Uganda

\begin{tabular}{|c|c|c|c|}
\hline \multicolumn{4}{|l|}{ Dependent variable: Proportion of HDDS by farmer household } \\
\hline Variable & Coefficient & Std. Error & P-Value \\
\hline Total land owned by household(ha) & 0.0002 & 0.00002 & 0.000 \\
\hline Household Tropical Livestock Units (TSLU) & 0.097 & 0.020 & 0.000 \\
\hline Farmer's experience in potato production & -0.017 & 0.005 & 0.001 \\
\hline Farmer is a $\mathrm{CC}$ project member $(\mathrm{Yes}=1, \mathrm{No}=0)$ & 0.015 & 0.101 & 0.882 \\
\hline Farmer crop diversification index & -0.503 & 0.452 & 0.265 \\
\hline $\begin{array}{l}\text { Potato commercialization } \\
\text { semi-commercial/commercial }=1 \text { ) }\end{array}$ & 0.033 & 0.102 & 0.749 \\
\hline Income (USh) from productive assets & $-1.66 \mathrm{e}-09$ & $5.08 \mathrm{e}-08$ & 0.973 \\
\hline Percentage of household income spent on food & 0.004 & 0.002 & 0.036 \\
\hline Total income earned from potato annually & $1.44 \mathrm{e}-11$ & $1.16 \mathrm{e}-11$ & 0.215 \\
\hline Education level of household head (years at school) & 0.029 & 0.013 & 0.025 \\
\hline Farmer's sex $($ male $=1$, female $=0)$ & 0.070 & 0.127 & 0.579 \\
\hline Age of household head & -0.003 & 0.004 & 0.477 \\
\hline Household Dependency (Number of dependants) & 0.028 & 0.022 & 0.211 \\
\hline $\begin{array}{l}\text { Woman decides how to use income from other crops other than } \\
\text { potato }\end{array}$ & 0.009 & 0.053 & 0.862 \\
\hline Woman participates in agricultural trainings & -0.030 & 0.106 & 0.776 \\
\hline
\end{tabular}

Model summary

Generalized linear models

Optimization : ML

Deviance $\quad=90.40248761$

Pearson $\quad=72.00508215$

Variance function: $\mathrm{V}(\mathrm{u})=\mathrm{u}^{*}(1-\mathrm{u} / 1)$

Link function $: g(\mathrm{u})=\ln (\mathrm{u} /(1-\mathrm{u}))$

Log pseudolikelihood $=-179.6155341$

$\begin{array}{lcc}\text { No. of obs } & = & 434 \\ \text { Residual df } & & 419 \\ \text { Scale parameter }= & 1 \\ (1 / \mathrm{df}) \text { Deviance }= & .2157577 \\ (1 / \mathrm{df}) \text { Pearson } & = & .1718498 \\ {[\text { Binomial }]} & \\ {[\text { Logit] }} & = \\ \text { AIC } & = & .8968458 \\ \text { BIC } & \end{array}$

In addition, a big and diversified number of animals (livestock and poultry) positively ( $\mathrm{P} \leq 0.01$ ) affect nutrition outcomes. Integration of livestock and poultry in potato production improves productivity of potato and other crops through use of manure. It also directly improves nutrition of the household and income through consumption and sale of livestock and poultry products, respectively. During the time of the study, very few households owned livestock. They could not access livestock manure, animal products (meat, milk, eggs) for income, and had limited dietary diversity. Results further show that farmer's experience in potato production significantly $(\mathrm{P} \leq 0.01)$ decreases household nutrition outcomes. Over time households perfect the production practices of the crop making it more readily for home consumption (increased dependency on it for food), yet the product does not provide a diet diversity.

On the other hand, education level of household head has a positive and significant $(\mathrm{P} \leq 0.05)$ influence on household nutrition outcomes. Education exposes household decision-makers on choices of what is to be eaten and health seeking behaviors. In Ethiopia, Gebre (2012) found a positive relationship between education level of household head and household food security. Nonetheless, participation in activities facilitated by the USAID Community Connector that exposes households to nutrition knowledge and interventions has no significant effect, largely because the households have not yet fully adopted the interventions. 
Finally, the percentage of household income spent on food positively $(\mathrm{P} \leq 0.05)$ affects household nutrition outcomes. Households that sell potato for income to buy food spend the income on a diversity of food types. However, results show that total income earned from potato and potato commercialization do not significantly affect household nutrition outcomes. The hypothesis that increased commercialization of potato in South-western Uganda negatively affect household nutrition outcomes by concentrating most of the resources to the enterprise at the expense of other food enterprises is rejected. Similarly, it is not empirically true that with potato commercialization, households get income that they use to buy a diversity of food types.

\subsection{Factors Affecting Household Food Security Outcomes}

The household food insecurity access scale (HFIAS) was used as a measure of household food security outcomes. Results from the regression model (Table 7) show that factors under production pathway (size of land owned, and farm crop diversification) and income pathway (income earned from potato) and gender pathway significantly enhanced household food security outcomes. The other significant enhancing factors are education level of household head, age of household head and famer's sex (male), while woman deciding how to use income from other crops other than potato has a negative effect.

Results indicate that an increase in the acreage of land owned by a household significantly $(\mathrm{P} \leq 0.05)$ reduces the threat of household food insecurity. Access to larger landholdings enables households to engage in relatively large scale production resulting into higher output. This is in line with findings by Conelly and Chaiken (2000) that small landholdings negatively impact on diet quality and food security. Similarly, farm crop diversification significantly $(\mathrm{P} \leq 0.05)$ enhances a household's food security outcome. Diversification reduces risks arising from seasonal crop failures. As expected, household income from potato also positively $(\mathrm{P}<0.10)$ affected food security outcomes. Households are able to stabilize consumption through the income earned; they also have assurance/confidence of food security given the marketability of the crop. Babatunde et al. (2007) similarly found that the higher the income, the more food secure the household were. Education is another important as regards the food security of a household. Results in Table 6 indicate that increase in formal education of the household head significantly $(\mathrm{P} \leq 0.01)$ increases household food security outcomes. This result is also supported by Babatunde et al. (2007) who found that households whose heads were more educated were more food secure. However, household size was found to significantly $(\mathrm{P} \leq 0.01)$ increase food insecurity of the household, with bigger households at a higher risk of being food insecure. This is expected in such areas as South-western Uganda where households face limited food and income sources, implying that an extra household member significantly reduces the per capita food availability. Similar observation was made by Haddad et al. (1994).

Table 7. Factors for potato farm household food security outcome

\begin{tabular}{lrrr}
\hline \multicolumn{4}{c}{ Dependent variable: Proportion of HFIAS score by farmer household } \\
Variable & Coefficient & Std. Error & P-Value \\
\hline Total land owned by household & -0.0001 & 0.000 & 0.033 \\
Household Tropical Livestock Units(TLSU) & -0.145 & 0.112 & 0.195 \\
Farmer is a CC project member (Yes=1, No=0) & -0.181 & 0.136 & 0.184 \\
Farmer's experience in potato production & 0.004 & 0.008 & 0.613 \\
Farm crop diversification index & -1.416 & 0.703 & 0.046 \\
Potato commercialization & 0.092 & 0.139 & 0.506 \\
semi-commercial/commercial=1) & & & \\
Total income earned from potato annually & & & \\
Income from productive assets & $-4.01 \mathrm{e}-09$ & $2.19 \mathrm{e}-09$ & 0.067 \\
Percentage of monthly household income spent on food & $-9.28 \mathrm{e}-08$ & $6.20 \mathrm{e}-08$ & 0.134 \\
Education level of household head (years at school) & 0.002 & 0.002 & 0.335 \\
Household size & -.0756 & 0.017 & 0.000 \\
Age of household head & 0.131 & 0.028 & 0.000 \\
Farmer's sex (male=1, female=0) & -0.014 & 0.006 & 0.011 \\
Woman decides how to use income from potato & -0.537 & 0.182 & 0.003
\end{tabular}




\begin{tabular}{|c|c|c|c|c|c|c|c|}
\hline \multicolumn{5}{|c|}{ Woman decides how to use income from other crops } & 0.215 & 0.073 & 0.003 \\
\hline \multicolumn{5}{|c|}{ Woman participates in agricultural trainings } & 0.082 & 0.150 & 0.587 \\
\hline \multicolumn{8}{|c|}{ Model summary } \\
\hline \multicolumn{2}{|c|}{ Generalized linear models } & No. of obs & $=$ & & & & \\
\hline Optimization & : ML & Residual df & $=$ & & & Scale parameter $=$ & 1 \\
\hline Deviance & $=97.79084965$ & (1/df) Deviance & $=.238$ & & $\mathrm{AIC}$ & $=.7445643$ & \\
\hline Log pseudolik & hood $=-143.2199165$ & $=-23$ & 383.566 & $=$ & 98.005065 & $(1 / \mathrm{df})$ Pearson $=$ & .2390367 \\
\hline Variance func & $\mathrm{n}: \mathrm{V}(\mathrm{u})=\mathrm{u}^{*}(1-\mathrm{u} / 1)$ & [Binomial] & & & & & \\
\hline Link function & $: g(u)=\ln (u /(1-u))$ & [Logit] & & & & & \\
\hline
\end{tabular}

Finally, a farmer being a woman, and a woman in a household having control over own earned incomes negatively and significantly $(\mathrm{P} \leq 0.01)$ affect household food security outcomes. In the study area, women culturally do not have as much control over productive resources which limits the amount of food they produce for their households. Regarding the control of income, women incomes are usually spent on non-food items such as clothing, medical care, and school requirements for their children, giving low priority to investing in food security interventions and/or buying adequate and nutritious foods. This is supported by Hyder et al. (2007) who found that lack of independent decision making for women who are responsible for food production and health of families has health and social consequences. It challenges some researchers who have recommended that women should be involved in the cash crop economy due to their influence in household nutrition (Longhurst, 1988), but in line with the assertion by Mehra and Rojas (2008) that the majority of women who farm live in male-headed households, and they also need development support including empowerment in control over resources for household food security.

\section{Conclusions and Recommendations}

Factors enhancing household nutrition outcomes among smallholder potato farmers were explored. These factors are under the three pathways, that is, farm production, income and gender pathways but most of the significant ones are under production pathway. Ownership of large size of land and livestock as well as education of household head are key in enhancing household nutrition outcomes. The outcomes are also enhanced by income earned from potato that has increasingly become a major food and cash crop in South-western Uganda. This leads us to the conclusion that potato enterprise is a good pathway for enhancing food and nutrition security in the area. However, the farm households are constrained by land shortage. Although their farming system is highly diversified, they lack a diversity of nutritious crops and livestock. Most of the crops grown provide starchy foods with limited dietary diversity. Very few households keep livestock and have access to animal protein. This study therefore recommends interventions that promote use of improved production practices to maximize productivity of the land and other farm resources. In addition, integration of livestock, especially the small ruminants and poultry, in potato production as a source of manure for improved soil fertility and diversified source of household nutrition should be promoted. The negative relationship of household food security outcome and farmer being a woman and woman having control over income from crops can be reversed by training women and men in household food and nutrition and related use of income. Another strategy is promoting gender-sensitive livestock projects such as rearing small ruminants (goats, sheep, and rabbits) and poultry which women have control over, and which they can easily convert into food.

\section{Acknowledgements}

We are grateful to the farmers, traders and processors in Kabale, Kisoro and Kanungu districts who spared their valuable time to participate in the study. We also thank various district officials in these district including KAZARDI and Local Government staff who gave us the information and guided us on our methodology. Field staff of the Community Connector Project did a great job in guiding the study team in the field.

\section{References}

Alemu, K. T. (2014). Potato value chain in Ethiopia: Cases of Sinan and Bibugn Districts in East Gojjam. Time Journals of Agriculture and Veterinary Sciences, 2(6), 114-124.

Altman, M., Hart, T. G., \& Jacobs, P. T. (2009). Household food security status in South Africa. Agrekon, 48(4), 345-361. https://doi.org/10.1080/03031853.2009.9523831 
Babatunde, R., Omotesho, O., \& Sholotan, O. (2007). Socio-economic characteristics and food security status of farming households in Kwara State, North-Central Nigeria. Pakistan Journal of Nutrition, 6(1), 49-58. https://doi.org/10.3923/pjn.2007.49.58

Campbell, C. C. (1991). Food insecurity: a nutritional outcome or a predictor variable? The Journal of Nutrition, 121(3), 408-415.

Coates, J., Swindale, A., \& Bilinsky, P. (2007). Household Food Insecurity Access Scale (HFIAS) for Measurement of Food Access: Indicator Guide VERSION 3. Food and Nutrition Technical Assistance, USAID.

Conelly, W. T., \& Chaiken, M. S. (2000). Intensive farming, agro-diversity, and food security under conditions of extreme population pressure in western Kenya. Human Ecology, 28(1), 19-51. https://doi.org/10.1023/A:1007075621007

de Vries, F. P., Rabbinge, R., \& Groot, J. J. R. (1997). Potential and attainable food production and food security in different regions. Philosophical Transactions of the Royal Society of London B: Biological Sciences, 352(1356), 917-928. https://doi.org/10.1098/rstb.1997.0071

Djebbari, H. (2005). The Impact on nutrition of the intrahousehold distribution of power. Institute for the Study of Labor, Bonn, Germany. Discussion Paper No. 1701.

Emana, B., \& Nigussie, M. (2011). Potato value chain analysis and development in Ethiopia Case of Tigray and SNNP Regions. International Potato Center, Ethiopia.

Fafchamps, M., Kebede, B., \& Quisumbing, A. R. (2009). Intrahousehold welfare in rural Ethiopia. Oxford Bulletin of Economics and Statistics, 71(4), 567-599. https://doi.org/10.1111/j.1468-0084.2009.00553.x

Faridi, R., \& Wadood, S. N. (2010). An econometric assessment of household food security in Bangladesh. The Bangladesh Development Studies, XXXIII, 97-111.

Gebre, G. G. (2012). Determinants of food insecurity among households in Addis Ababa City, Ethiopia. Interdisciplinary Description of Complex Systems, 10(2), 159-173. https://doi.org/10.7906/indecs.10.2.9

Gillespie, S., Harris, J., \& Kadiyala, S. (2012). The Agriculture-Nutrition Disconnect in India: What Do We Know? International Food Policy Research Institute, IFPRI Discussion Paper 01187.

Haddad, L., Kennedy, E., \& Sullivan, J. (1994). Choice of indicators for food security and nutrition monitoring. Food Policy, 19(3), 329-343. https://doi.org/10.1016/0306-9192(94)90079-5

Hawkes, C., \& Ruel, M. T. (2011). Value chains for nutrition. Prepared for IFPRI 2020 international conference "Leveraging Agriculture for Improving Nutrition and Health," February 10-12, 2011, New Delhi, India.

Herforth, A., \& Jody, H. (2014). Understanding and Applying Primary Pathways and Principles. Brief \#1. Improving Nutrition through Agriculture Technical Brief Series. Arlington, VA: USAID/Strengthening Partnerships, Results, and Innovations in Nutrition Globally (SPRING) Project.

Hilbe, J. M. (1994). Generalized linear models. The American Statistician, 48(3), 255-265. https://doi.org/10.1080/00031305.1994.10476073

Hoeffler, H. (2006). Promoting The Kenyan Potato Value Chain: Can Contract Farming Help Build Trust and Reduce Transaction Risks? Paper prepared for presentation at the 99th EAAE Seminar, February 8-10, 2006, Bonn, Germany.

Hyder, A. A., Maman, S., Nyoni, J. E., Khasiani, S. A., Teoh, N., Premji, Z., \& Sohani, S. (2007). The pervasive triad of food security, gender inequity and women's health: exploratory research from sub-Saharan Africa. African Health Sciences, 5(4), 328-334.

Immink, M. D., \& Alarcón, J. A. (1992). Household food security and crop diversification among smallholder farmers in Guatemala. Food Nutrition and Agriculture, (4).

Kikafunda, J. K., Agaba, E., \& Bambona, A. (2014). Malnutrition amidst plenty: An assessment of factors responsible for persistent high levels of childhood stunting in food secure western Uganda. African Journal of Food, Agriculture, Nutrition and Development, 14(5), 2088-2113.

Kyomugisha, H., Mugisha, J., \& Sebatta, C. (2016). Potential determinants of profits and market efficiency of potato market chains in Uganda. Journal of Agribusiness in Developing and Emerging Economies.

Leliveld, A., Dietz, T., Foeken, D., \& Klaver, W. (2013). Agricultural dynamics and food security trends in Uganda . Developmental Regimes in Africa (DRA) Project ASC-AFCA Collaborative Research Group: 
Agro-Food Clusters in Africa (AFCA). Research Report 2013-ASC-2, 45pp.

Lemaga, B. (2010). The potato value chain in sub-Saharan Africa with case study on Eastern Africa. In Cromme N., Prakash A. B., Lutaladio N., \& Ezeta F. (Eds.), Strengthening potato value chains: Technical and policy options for developing countries. Food and Agriculture Organization of the United Nations and the Common Fund for Commodities, Rome.

Longhurst, R. (1988). Cash crops, household food security and nutrition1. IDS Bulletin, 19(2), 28-36. https://doi.org/10.1111/j.1759-5436.1988.mp19002005.x

Maxwell, S., \& Smith, M. (1992). Household food security: a conceptual review. In Maxwell S., \& Frankenberger T. (Eds.), Household Food Security: concepts, indicators, measurements. Rome and New York: IFAD and UNICEF.

McCullagh, P. (1980). Regression models for ordinal data. Journal of the Royal Statistical Society. Series B (Methodological), 109-142.

Mehra, R., \& Rojas, M. H. (2008). Women, food security and agriculture in a global marketplace. International Center for Research on Women (ICRW).

Mutunga, S. L. (2014). Potato market survey in Kenya: An agricultural product value chain approach. International Journal of Business and Management Review, 2(6), 59-87.

Oluyole, K. A., Oni, O. A., Omonona, B. T., \& Adenegan, K. O. (2009). Food security among cocoa farming households of Ondo State, Nigeria. Journal of Agricultural and Biological Science, 4(5), 7-13.

Otunaiya, A. O., \& Ibidunni, O. S. (2014). Determinants of food security among rural farming households in Ogun State, Nigeria. Journal of Sustainable Development in Africa, 16(6), 33-44.

Quisumbing, A. R., \& Maluccio, J. A. (2003). Resources at Marriage and Intrahousehold allocation: Evidence from Bangladesh, Ethiopia, Indonesia, and South Africa. Oxford Bulletin of Economics and Statistics, 65(3), 283-327. https://doi.org/10.1111/1468-0084.t01-1-00052

Rahim, S., Saeed, D., Rasoo, G. A., \& Saeed, G. (2011). Factors influencing household food security status. Food and Nutrition Sciences, 2, 31-34. https://doi.org/10.4236/fns.2011.21004

Sebatta, C., Mugisha, J., Katungi, E., Kashaaru, A., \& Kyomugisha, H. (2014). Smallholder farmers' decision and level of participation in the potato market in Uganda. Modern Economy, 5, 895-906. http://dx.doi.org/10.4236/me.2014.58082

Swindale, A., \& Bilinsky, P. (2005). Household Dietary Diversity Score (HDDS) for Measurement of Household Food Access: Indicator Guide. Food and Nutrition Technical Assistance Project (FANTA).

UNEP. (2016). Food Systems and Natural Resources. A Report of the Working Group on Food Systems of the International Resource Panel. Westhoek, H, Ingram J., Van Berkum, S., Özay, L., and Hajer M.

Whitehead, A. (1990). Rural women and food production in Sub-Saharan Africa. In Dreze J., \& Sen A. (Eds.), The political economy of hunger: Entitlement and well-being (Vol. 1, pp. 425-473). Oxford. Clarendon Press.

World Bank. (2007). From Agriculture to Nutrition: Pathways, Synergies, and Outcomes. The International Bank for Reconstruction and Development, Washington D.C.

Zakari, S., Ying, L., \& Song, B. (2014). Factors influencing household food security in West Africa: The case of Niger. Sustainability, 6, 1191-1202. Retrieved from http://www.mdpi.com/journal/sustainability

\section{Copyrights}

Copyright for this article is retained by the author(s), with first publication rights granted to the journal.

This is an open-access article distributed under the terms and conditions of the Creative Commons Attribution license (http://creativecommons.org/licenses/by/4.0/). 